\title{
Absence of bacterial resistance to povidone iodine
}

\author{
ELIZABETH T. HOUANG, O. J. A. GILMORE, CLARE REID, AND \\ ELIZABETH J. SHAW
}

From the Department of Medical Microbiology and the Surgical Professorial Unit, St. Bartholomew's Hospital, London

SYNOPSIS Povidone iodine is now being increasingly used in hospitals as an antiseptic. The possible habituation of bacteria to iodine was studied by serial passage of two strains of Pseudomonas aeruginosa, two strains of Escherichia coli, two strains of Klebsiella aerogenes, and one strain of Serratia marcescens in subinhibitory concentrations. After 20 passages, no significant change was observed in the minimal inhibitory concentration, minimal bactericidal concentration, and killing times between parent strains and 20th subcultures under standardized conditions.

Iodine has been recognized as an effective bactericide for over a century (Davaine, 1873), but its use is not as wide as one might expect. This is because it is relatively insoluble in water, chemically unstable, irritant to the tissue, and liable to cause sensitivity reactions in some patients. Povidone iodine, a complex of the polymer polyvinylpyrrolidone and iodine (Siggia, 1957), is, on the other hand, a watersoluble, chemically stable form of iodine which is non-irritant to the tissues and does not cause reactions in patients sensitive to elemental iodine on patch testing (Shelanski and Shelanski, 1956).

Povidone iodine retains all the desirable bactericidal properties of elemental iodine without any of its disadvantages. It is therefore not surprising that this antiseptic is now widely used in hospitals as a surgical scrub and for skin disinfection. It has also been recommended in the treatment of burns (Wynn-Williams and Monballiu, 1965) and varicose ulcers (Thorne and Fox, 1965), and as a shampoo (Dineen and Drusin, 1973) and vaginal disinfectant (Duignan and Lowe, 1975). Recently, a dry powder aerosol formulation has been shown in controlled trials to be effective in preventing postoperative wound infection (Gilmore et al, 1973; Gilmore and Martin, 1974; Gilmore and Sanderson, 1975a).

To date the development of bacterial resistance to povidone iodine has not been reported. For this reason it has been suggested that povidone iodine offers a preferable alternative to antibiotics in the prophylaxis of wound infection (Gilmore and Sanderson, 1975b). Recently, a povidone iodine spray was launched on the retail market (Higgins,

Received for publication 20 January 1976
1975). The present study was undertaken therefore to determine whether bacterial resistance to povidone iodine could be induced in vitro.

\section{Material and methods}

Seven strains of bacteria were used in the study:

1 Pseudomonas aeruginosa - an unidentified environmental strain isolated from a medicament

2 Pseudomonas aeruginosa NCTC 5525

3 Escherichia coli $0111 / \mathrm{B} 4 / \mathrm{H} 2$ - a clinical isolate

4 Escherichia coli $0141 / \mathrm{K} 85 / \mathrm{H} 4$ - a clinical isolate

5 Klebsiella aerogenes - a clinical isolate

6 Klebsiella aerogenes - a clinical isolate

7 Serratia marcescens-a clinical isolate

A minimal salt solution containing $0.2 \%$ glucose was made up according to the formula and method recommended by Datta (1968). A single batch of this solution was used throughout the experiment.

\section{SERIAL PASSAGE}

The seven strains of organism were initially cultured aerobically in minimal salt solution with $0.2 \%$ glucose for 48 hours at $37^{\circ} \mathrm{C}$. $0.04 \mathrm{ml}$ volumes of these cultures were then inoculated into a set of tubes containing a freshly prepared double dilution series of povidone iodine in $1 \mathrm{ml}$ of minimal salt solution with $0.2 \%$ glucose. Each set of tubes also included two controls, one containing minimal salt solution and $0.2 \%$ glucose, the other minimal salt solution, $0.2 \%$ glucose, and a similar inoculum of bacteria. All tubes were incubated at $37^{\circ} \mathrm{C}$ and examined after 48 hours for bacterial growth. When visible growth was present samples $(0.4 \mathrm{ml})$ were taken from the tube containing the highest concentration of 
povidone iodine allowing bacterial growth and inoculated into a fresh set of tubes containing a similar range of povidone iodine concentrations.

Each organism was passaged 20 times. After 20 transfers the killing times of the parent strains and their 20th subcultures were determined.

\section{DETERMINATION OF MINIMAL INHIBITORY}

AND BACTERICIDAL CONCENTRATIONS

(MIC AND MBC)

At the end of the experiments the MIC and MBC of the parent strains and their 20th subcultures were determined simultaneously. A series of double dilutions of $1 \%$ povidone iodine solution were made up in large volumes (master dilution) in minimal salt solution with $0.2 \%$ glucose. Each dilution was then distributed into $1 \mathrm{ml}$ volumes. Thus many sets of double dilutions were obtained from the same master solution. A $0.04 \mathrm{ml}$ volume of a 48 -hour culture in minimal salt solution with $0.2 \%$ glucose was used as the inoculum. After 48 hours' incubation at $37^{\circ} \mathrm{C}$ all tubes were examined for bacterial growth. The highest dilution showing visible growth was taken as the minimal inhibitory concentration. Subcultures onto blood agar plate (Oxoid) were made from tubes without visible turbidity. The highest dilution showing bacterial growth after 24 hours' incubation at $37^{\circ} \mathrm{C}$ was taken as the minimal bactericidal concentration.

\section{DETERMINATION OF KILLING TIME}

$0.3 \mathrm{ml}$ of an overnight nutrient broth (Oxoid No. 2) culture of each parent strain and its 20th subculture was inoculated into $3 \mathrm{ml}$ of pure povidone iodine solution containing $0.1 \%, 0.01 \%$, and $0.001 \%$ available iodine. Standard $4 \mathrm{~mm}$ loop samples were then taken from the povidone iodine solutions after $15,30,45$ seconds, $1,2,3,4,5$ and 10 minutes and inoculated into $3 \mathrm{ml}$ of nutrient broth (Oxoid No. 2) containing $1 \%$ sodium thiosulphate, the presence of sodium thiosulphate being necessary to neutralize any povidone iodine carried over. After 48 hours' incubation at $37^{\circ} \mathrm{C}$ all tubes were examined for turbidity and subcultured.

All povidone iodine solutions used in the study were assayed for available iodine content by titration with freshly prepared $0.01 \mathrm{~N}$ sodium thiosulphate.

\section{Results}

The actual concentration of the percentage available iodine present in the double dilution series in minimal salt solution is given in table $I$. Between dilutions of 1 in 16 and 1 in 128 inclusive, the level of available iodine is only approximately half that of the expected value. Beyond a dilution of 1 in 128 the loss

\begin{tabular}{lll}
\hline Dilution & \multicolumn{2}{l}{$\%$ Available Iodine } \\
\cline { 2 - 3 } & Expected & Actual \\
\hline 1 in 1 & 1 & 1 \\
1 in 2 & $0 \cdot 5$ & $0 \cdot 5$ \\
1 in 4 & $0 \cdot 25$ & $0 \cdot 25$ \\
1 in 8 & $0 \cdot 125$ & $0 \cdot 125$ \\
1 in 16 & $0 \cdot 0625$ & $0 \cdot 036$ \\
1 in 32 & 0.03125 & $0 \cdot 017$ \\
1 in 64 & 0.0156125 & 0.008 \\
1 in 128 & 0.0078062 & 0.003 \\
1 in 256 & $0 \cdot 0039031$ & $0 \cdot 0009$ \\
1 in 512 & 0.0019515 & Non assayable \\
1 in 1024 & 0.0009757 & Non assayable \\
1 in 2048 & 0.0004878 & Non assayable \\
\hline
\end{tabular}

Table I Available iodine content of various dilutions of povidone iodine in minimal salt solution containing $0 \cdot 2 \%$ glucose

of available iodine is even greater, so that at a dilution of 1 in 1024, if any iodine was present, it was not assayable. The pure solutions of povidone iodine used for the killing time determinations, however, were found on assay to contain their expected amount of available iodine.

The minimal inhibiting concentrations (MIC) and the minimal bactericidal concentrations (MBC) of the parent strains and their 20th subcultures are given in table II. After 20 passages the MIC and $\mathrm{MBC}$ for all seven strains remained virtually unchanged.

The killing times of each parent strain and its 20th subculture are given in table III. Again there is no significant difference. The killing times of both strains of Ps. aeruginosa were longer than those of the other organisms tested, but there was no difference between the parent strain and its 20th subculture. Povidone iodine solutions containing $0 \cdot 1 \%$ available iodine killed all strains within 5 minutes, and the majority within 30 seconds.

The results (table III) show that for dilutions containing $0.01 \%$ available iodine or less to kill bacteria a contact time in excess of 10 minutes is generally required. However, the MIC/MBC study (table II) shows that minute quantities of iodine killed all the strains tested, on prolonged exposure.

\section{Discussion}

When iodine and polyvinylpyrrolidone are mixed there is some chemical reaction between the two; the iodine oxidizes the unsaturated end groups in the polyvinylpyrrolidone, resulting in the formation of a certain amount of iodide ion. About two-thirds of the original iodine, however, remains as iodine. This is titratable with sodium thiosulphate and called free or available iodine, since it is the effective form of 


\begin{tabular}{|c|c|c|c|c|c|c|c|c|}
\hline & \multirow[b]{3}{*}{$\begin{array}{l}\text { Dilution Ratio of } \\
1 \% \text { Solution }\end{array}$} & \multicolumn{7}{|l|}{ Strain } \\
\hline & & 1 & 2 & 3 & 4 & 5 & 6 & 7 \\
\hline & & $\begin{array}{l}\text { Ps. aeru- } \\
\text { ginosa } 1\end{array}$ & $\begin{array}{l}\text { Ps. aeru- } \\
\text { ginosa } 2\end{array}$ & $\begin{array}{l}\text { E. coli } \\
0111 / \mathrm{B} 4 / \mathrm{H} 2\end{array}$ & $\begin{array}{l}\text { E. coli } \\
0141 / \mathrm{K} 85 / \mathrm{H} 4\end{array}$ & $\begin{array}{l}\text { K. aerogenes } \\
1\end{array}$ & $\begin{array}{l}\text { K. aerogenes } \\
2\end{array}$ & S. marcescens \\
\hline $\begin{array}{l}\text { Parent strains } \\
\text { 20th subculture }\end{array}$ & $\begin{array}{l}\text { MIC } \\
\text { MBC } \\
\text { MIC } \\
\text { MBC }\end{array}$ & $\begin{array}{l}1: 1024 \\
1: 512 \\
1: 1024 \\
1: 512\end{array}$ & $\begin{array}{l}1: 512 \\
1: 256 \\
1: 256 \\
1: 256\end{array}$ & $\begin{array}{l}1: 4096 \\
1: 4096 \\
1-8192 \\
1: 8192\end{array}$ & $\begin{array}{l}1: 2048 \\
1: 2048 \\
1: 4096 \\
1: 4096\end{array}$ & $\begin{array}{l}1: 4096 \\
1: 4096 \\
1: 4096 \\
1: 2048\end{array}$ & $\begin{array}{l}1-4096 \\
1: 2048 \\
1: 4096 \\
1: 4096\end{array}$ & $\begin{array}{l}1: 8192 \\
1: 8192 \\
1: 8192 \\
1: 8192\end{array}$ \\
\hline
\end{tabular}

Table II Minimal inhibitory and bactericidal concentrations of povidone iodine

\begin{tabular}{|c|c|c|c|c|c|}
\hline & \multicolumn{2}{|l|}{ Organism } & \multicolumn{3}{|c|}{ Concentration of Available Iodine } \\
\hline & & & $0.1 \%$ & $0.01 \%$ & $0.001 \%$ \\
\hline 1 & \multirow{7}{*}{$\begin{array}{l}\text { Ps. aeruginosa } \\
1 \\
\text { Ps. aeruginosa } \\
2 \\
\text { E. coli } \\
0111 / \mathrm{B} 4 / \mathrm{H} 2 \\
\text { E. coli } \\
0141 / \mathrm{K} 85 / \mathrm{H} 4 \\
\text { K. aerogenes } \\
1 \\
\text { K. aerogenes } \\
2 \\
S . \text { marcescens }\end{array}$} & \multirow{7}{*}{$\begin{array}{l}\mathbf{P} \\
\mathbf{N} \\
\mathbf{P} \\
\mathbf{N} \\
\mathbf{P} \\
\mathbf{N} \\
\mathbf{P} \\
\mathbf{N} \\
\mathbf{P} \\
\mathbf{N} \\
\mathbf{P} \\
\mathbf{N} \\
\mathbf{P} \\
\mathbf{N}\end{array}$} & \multirow{7}{*}{$\begin{array}{l}1 \mathrm{~min} \\
45 \mathrm{~s} \\
5 \mathrm{~min} \\
4 \mathrm{~min} \\
15 \mathrm{~s} \\
15 \mathrm{~s} \\
15 \mathrm{~s} \\
15 \mathrm{~s} \\
15 \mathrm{~s} \\
15 \mathrm{~s} \\
1 \mathrm{~min} \\
45 \mathrm{~s} \\
30 \mathrm{~s} \\
30 \mathrm{~s}\end{array}$} & \multirow{7}{*}{$\begin{array}{l}\mathbf{G} \\
\mathbf{G} \\
\mathbf{G} \\
\mathbf{G} \\
\mathbf{G} \\
\mathbf{G} \\
\mathbf{G} \\
\mathbf{G} \\
\mathbf{G} \\
\mathbf{G} \\
\mathbf{3} \mathrm{min} \\
\mathbf{G} \\
\mathbf{G} \\
10 \mathrm{~min}\end{array}$} & $\mathbf{G}$ \\
\hline & & & & & Not done \\
\hline 3 & & & & & $\begin{array}{l}\mathbf{G} \\
\mathbf{G}\end{array}$ \\
\hline 4 & & & & & $\begin{array}{l}\mathbf{G} \\
\mathbf{G}\end{array}$ \\
\hline 5 & & & & & $\begin{array}{l}\mathbf{G} \\
\mathbf{G}\end{array}$ \\
\hline 6 & & & & & $\begin{array}{l}\mathbf{G} \\
\mathbf{G}\end{array}$ \\
\hline 7 & & & & & $\begin{array}{l}G \\
10 \min \end{array}$ \\
\hline
\end{tabular}

Table III Killing time of each parent strain and its 20th subculture

$G=$ growth present in subculture made at $10 \mathrm{~min}$

$P$ = parent strain

$\mathbf{N}=20$ th subculture

iodine available for bactericidal purposes. The iodide ion content accounts for the remainder of the iodine except for a very small percentage which becomes organically linked.

Since the available iodine is the active fraction in povidone iodine it is important to ensure its presence in any solution used for experiments on the possible habituation of bacteria to povidone iodine. Minimal salt solution with $0.2 \%$ glucose was found satisfactory both as a growth medium for the organisms tested and as a diluent which allowed a certain amount of available iodine to remain in solution. Solutions richer in organic matter, for example, peptone water, caused a greater loss of available iodine than did the minimal salt solutions. It was hoped that, by using the same batch of minimal salt solution, the same stock solution of povidone iodine, and the same technique of dilution throughout the experiment the consistency of the various concentrations from transfer to transfer would be maintained.

The present study showed that after 20 passages there was no increase in the MIC, MBC or killing time of the seven strains of bacteria used. This is of interest since resistance, both in vitro and in vivo, to other antiseptics has been reported.
The first such report appeared in 1887 when Kossiakoff described that Bacillus subtilis developed a reduction in sensitivity to mercuric chloride and boric acid on prolonged 'acclimitization' experiments. Resistance to the other commonly used metallic salt, silver nitrate, has also been reported (Cason et al, 1966). Berger and Wyss (1953) found Staphylococcus aureus mutants resistant to the bacteriostatic action of phenol. These same bacteria were also found to be resistant to its bactericidal action when grown in subinhibitory concentrations. Thornley and Yudkin (1959) showed resistance to proflavin due to mutation and selection occurring simultaneously in Esch. coli and Aerobacter aerogenes.

Bacteria readily develop resistance to the quaternary ammonium compounds (Chaplin, 1952). MacGregor and Elliker (1958) raised the tolerance of $P s$. aeruginosa to quaternary compounds sevenfoldfrom 100 to 700 parts per million after nine transfers in a liquid medium, and ultimately to 2000 parts per million. Increased tolerance of Gram-negative bacteria to these antiseptics has also been reported by Soprey and Maxcy (1968). Organisms resistant to chlorhexidine have been reported by Gillespie et al (1967), Stickler (1974), and Maurer (1974). Stickler found that four transfers induced significant resistance in Proteus mirabilis, while Maurer found three transfers at weekly intervals sufficient in the case of Ps. aeruginosa.

There was no evidence from studies on seven bacterial strains that any reduction in sensitivity occurs on repeated exposure of bacteria to povidone iodine. This is an important finding in view of the increasing use being made of this valuable antiseptic in both hospitals and the home.

We are grateful to Dr G. Batistoni for the assays of iodine. O. J. A. Gilmore is most grateful to the Joint Research Board of St. Bartholomew's Hospital for the Aylwen bursary of which he was in receipt during his study.

References

Berger, H. and Wyss, O. (1953). Studies on bacterial resistance $\bar{v}$ 
to inhibition and killing by phenol. J. Bact., 65, 103-110.

Cason, J. S., Jackson, D. M., Lowbury, E. J. L., and Ricketts, C. R. (1966). Antiseptic and aseptic prophylaxis for burns: use of silver nitrate and of isolators. Brit. med. J., 2, 12881294.

Chaplin, C. E. (1952). Bacterial resistance to quaternary ammonium disinfectants. J. Bact., 63, 453-458.

Datta, N. (1968). Acquisition of antibiotic resistance by bacteria. In Recent Advances in Clinical Pathology, Series V, edited by S. C. Dyke, p. 51. Churchill, London.

Davaine, C. (1873). Cited by Vallin, E. Gérardin, A. (1883). Dictionnaire Encyclopédique des Sciences Médicales, edited by A. Dechambre, Ser. 1, 28 (art. Désinfectants), pp. 336337. P. Asselin and G. Masson, Paris.

Dineen, P. and Drusin, L. (1973). Epidemics of postoperative wound infections associated with hair carriers. Lancet, 2, 1157-1159.

Duignan, N. M. and Lowe, P. A. (1975). Preoperative disinfection of the vagina. J. antimicrob. Chemother., 1, 117-120.

Gillespie, W. A., Lennon, G. C., Linton, K. B., and Phippen, G. A. (1967). Prevention of urinary infection by means of closed drainage into a sterile plastic bag. Brit. med. J., 3, 90-92.

Gilmore, O. J. A. and Martin, T. D. M. (1974). Aetiology and prevention of wound infection in appendicectomy. Brit. J. Surg., 61, 281-287.

Gilmore, O. J. A., Martin, T. D. M., and Fletcher, B. N. (1973). Prevention of wound infection after appendicectomy. Lancet, 1, 220-222.

Gilmore, O. J. A., and Sanderson, P. J. (1975a). Prophylactic interparietal povidone-iodine in abdominal surgery. Brit. J. Surg., 62, 792-799.
Gilmore, O. J. A. and Sanderson, P. J. (1975b). An antibiotic policy for surgical patients. Ann. roy. Coll. Surg. Eng., 57, 204-211.

Higgins, D. G. (1975). Povidone iodine: the tamed iodine. Chem. and Drugg., 204, 274-775.

Kossiakoff, G. (1887). De la propriété que possèdent les microbes de s'accommoder aux milieux antiseptiques. $A \boldsymbol{n}$. Inst. Pasteur, 1, 465-476.

MacGregor, D. R. and Elliker, P. R. (1958). A comparison of some properties of strains of Pseudomonas aeruginosa sensitive and resistant to quaternary ammonium compounds. Canad. J. Microbiol., 4, 499-503.

Maurer, I. M. (1974). Hospital Hygiene, pp. 54-55. Edward Arnold, London.

Shelanski, H. A. and Shelanski, M. V. (1956). PVP-iodine: history, toxicity and therapeutic uses. J. int. Coll. Surg., 25, 727-734.

Siggia, S. (1957). The chemistry of polyvinylpyrrolidoneiodine. J. Amer. pharm. Ass., Sci. Ed., 46, 201-204.

Soprey, P. R. and Maxcy, R. B. (1968). Tolerance of bacteria to quaternary ammonium compounds. J. Food Sci., 33, 536-540.

Stickler, D. J. (1974). Chlorhexidine resistance in Proteus mirabilis. J. clin. Path., 27, 284-287.

Thorne, N. and Fox, D. (1965). A trial of povidone-iodine ointment in the treatment of leg ulcers. Practitioner, 194, 250-253.

Thornley, M. J. and Yudkin, J. (1959). The origin of bacterial resistance to proflavine. 1 . Training and reversion in Escherichia coli. J. gen. Microbiol., 20, 355-364.

Wynn-Williams, D. and Monballiu, G. (1965). The effects of povidone-iodine in the treatment of burns and traumatic losses of skin. Brit. J. plast. Surg., 18, 146-150. 